\title{
龁黑溫泉成因の化學的研究 (第二報)
}

(昭和十三年一月十一日受领)

$$
\text { 三浦䇈次郎 }
$$

\section{I. 噴出瓦斯定量試驗}

瓦斯の定量分析に當つて特に注意した事は，(1) 躓出瓦斯に空氣の少しる混入する事なく捕集する 事，(2) 捕集せる瓦斯成分几變化の起らざる中に分析する事，(3) 分析操作中にる空氣の混入を防を 成る可く精密に分析する事であつれ，此の中（2）の條件を洋足せしむるには現地分析をせ权ぱるら 々事が豫想されたのであつたが經費その他の點で最初は不可能であつたので昭和 5 年及び 6 年には 現地にて 捕集した瓦斯を歸校後定量分析して上記の條件を滿足せしぬられるかどうか孝試驗した。 その結果は滿足なるのではなかつちので, 昭和 5 年及び 6 年に行つを絬果は結局豫薉試驗の範園を出

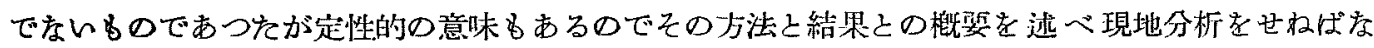
らなかつを理由を說明する事とする。

1. 豫備試驗 昭和 5 年度には大沸，湯花朋水阴附近及び赤噌の主に水中ょり貲出する瓦斯を捕集 した. 捕集裝置は第2 2 圖と大體同樣の裝置を用ひ同樣の方法にて捕集し河水中より捕集せるるのは

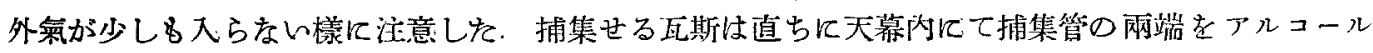
ランプにて熔封した．熔封の際には充分注意を抈んが歸校後取り出したところ11本の中1播のみ 熔封完全であつたが2番より11番迄は熔扵部に破目が人つてるたので直ちにヘンペル法にて吸收

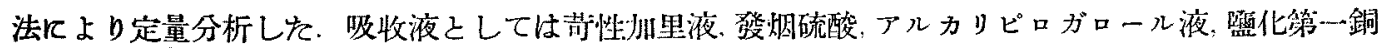

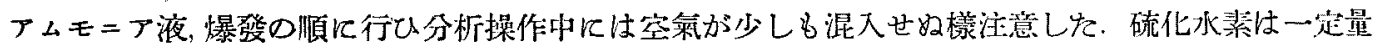

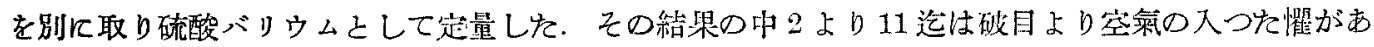

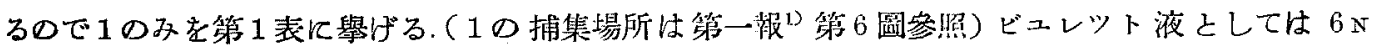

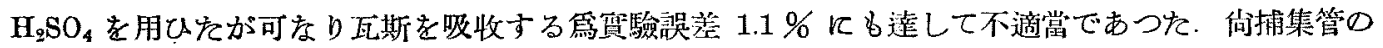

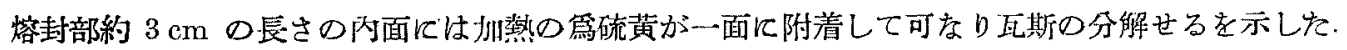

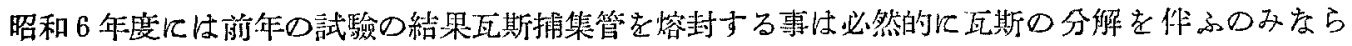

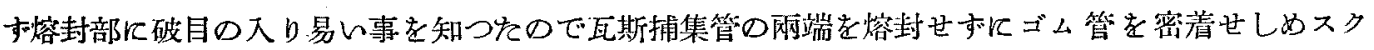

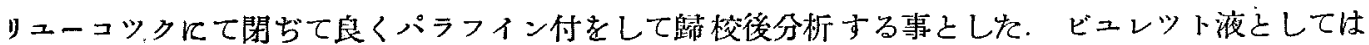

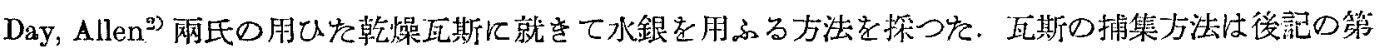

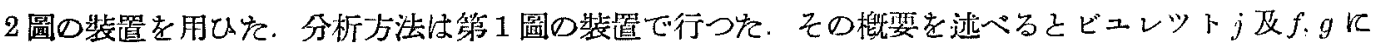

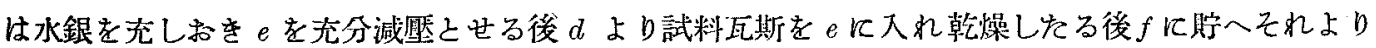

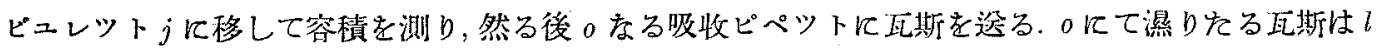

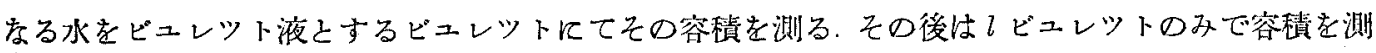

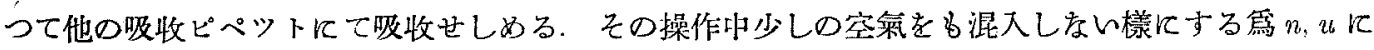
は水を入れ就を調節した $j, l$ なるビュレツトは $0.1 \mathrm{cc}$ 目盛の $50 \mathrm{cc}$ 容量のるので豫め水銀及び水で

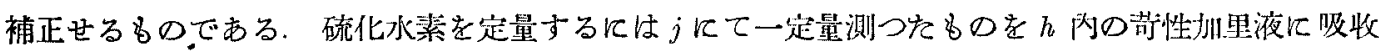

1) 本誌. 59 (1933), 178. 2) Day, Allen: "The Volcanic activity and hot springs of Lassen Peak" Carneg. Inst. Washington No. 360, (1925), 124. 


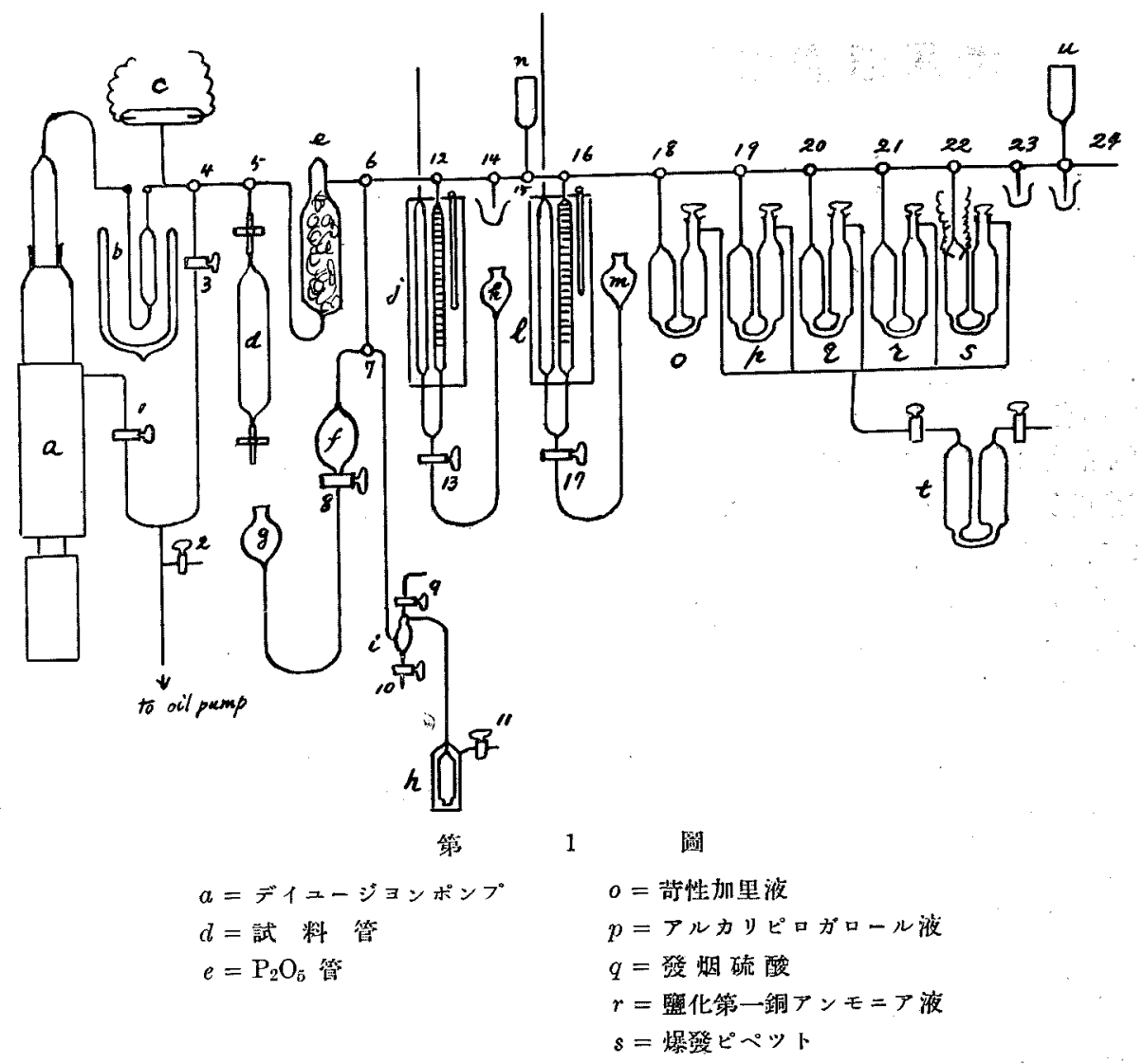

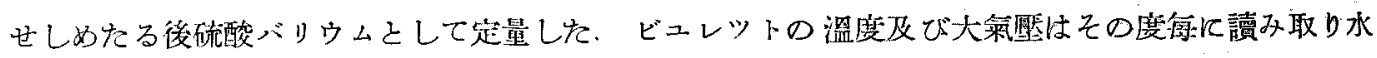

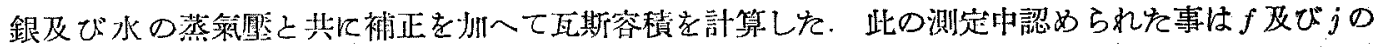
水銀が黑變し硫化水銀を生じた事で, 此れは $e$ による乾燥が不完全なりしによると考へられるのであ

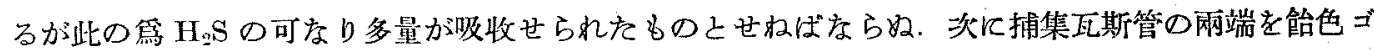
ム管にて封じて持つて䟥つたのであるが分析に際して取り出したところ飴色ゴム管中には黑變せる

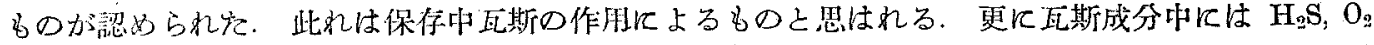

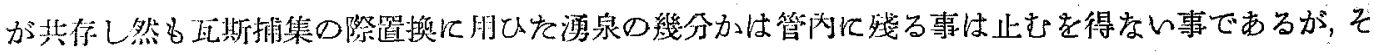

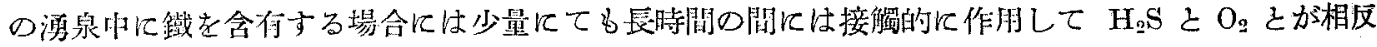

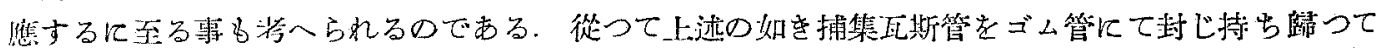

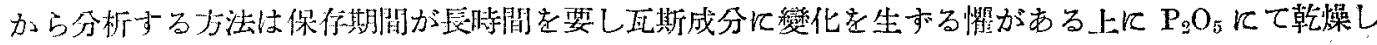
水銀をビュレツト液とする分析法も滿足なる絈果を得られなかつちので,かくの如くにして得られた

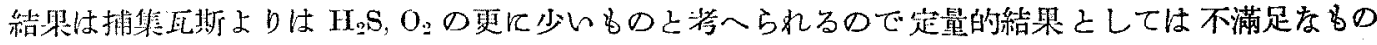

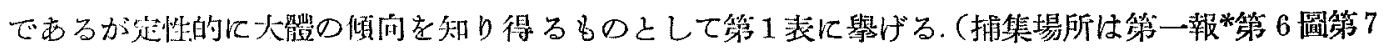

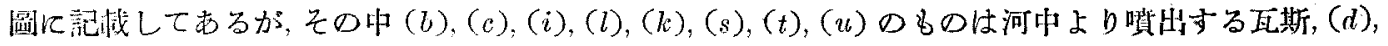

* 前什. 


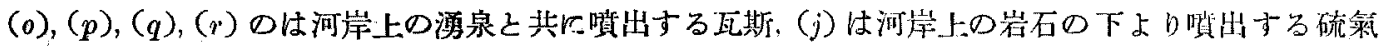
孔瓦斯で孔口は硫黄の結晶にて塞がれてるるるのであつた.)

第 1 表 幊出瓦斯成分表 (昭和 5 年, 昭和 6 年)

\begin{tabular}{|c|c|c|c|c|c|c|c|c|c|c|c|c|}
\hline \multirow{2}{*}{$\begin{array}{l}\text { 實 驗 } \\
\text { 番 號 }\end{array}$} & \multirow{2}{*}{ 場 } & \multirow{2}{*}{\multicolumn{2}{|c|}{$\begin{array}{l}\text { 特 } \\
\text { 年. } \\
\text { (昭和) }\end{array}$}} & \multirow{2}{*}{ 日 } & \multirow{2}{*}{$\begin{array}{c}\text { 溫 度 } \\
{ }^{\circ} \mathrm{C}\end{array}$} & \multirow{2}{*}{$\begin{array}{c}\text { 大氯瓶 } \\
\mathrm{mm}\end{array}$} & \multirow{2}{*}{$\begin{array}{c}\text { 深 さ } \\
\mathrm{cm}\end{array}$} & \multicolumn{4}{|c|}{ 瓦 斯 成 分 (\%) } & \multirow{2}{*}{$\frac{\mathrm{N}_{2}}{\mathrm{O}_{2}}$} \\
\hline & & & & & & & & $\mathrm{CO}_{2}$ & $\mathrm{H}_{2} \mathrm{~S}$ & $\mathrm{O}_{2}$ & $\mathrm{~N}_{2}$ & \\
\hline 1 & 大沸 & 5. & 8. & 11 & 95.5 & & & 78 & 11 & 2 & 9 & 4.5 \\
\hline 12 & " & 6. & 8. & 6 & & & 140 & 84.64 & 2.25 & 2.22 & 10.89 & 4.91 \\
\hline 13 & " & 6. & 8. & 7 & & & 140 & 75.63 & 2.40 & 4.35 & 17.62 & 4.05 \\
\hline 14 & $\prime$ & 6. & 8. & 7 & & & 100 & 80.07 & 8.50 & 1.57 & 9.86 & 6.28 \\
\hline 15 & $"$ & 6. & 8. & 7 & & & 100 & 80.86 & 5.61 & 1.79 & 11.74 & 6.56 \\
\hline 16 & $"$ & 6. & 8. & 7 & 92.8 & 690.5 & 13 & 81.61 & 8.50 & 0.63 & 9.26 & 14.70 \\
\hline 17 & $"$ & 6. & 8. & 7 & & & 13 & 78.26 & 5.01 & 2.63 & 14.10 & 5.36 \\
\hline 18 & $"$ & 6. & 8. & 7 & 93.5 & 699.5 & 15 & 80.06 & 1.90 & 0.22 & 17.82 & 81.00 \\
\hline 20 & 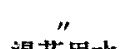 & 6. & 8. & 7 & 98.0 & 699.5 & & 68.07 & 18.73 & 2.53 & 10.67 & 4.22 \\
\hline 21 & 潩花用水 & 6. & 8. & 4 & & & 56 & 87.13 & 4.53 & 1.54 & 6.80 & 4.42 \\
\hline 22 & . & 6. & 8. & 4 & & & 56 & 89.52 & 1.40 & 0.39 & 8.69 & 22.28 \\
\hline 23 & $"$ & 6. & 8. & 6 & 69.7 & 696.5 & 2 & 87.69 & 5.97 & 1.00 & 5.34 & 5.34 \\
\hline 24 & $"$ & 6. & 8. & 6 & & & 2 & 86.12 & 4.96 & 1.69 & 7.23 & 4.28 \\
\hline 25 & $"$ & 6. & 8. & 8 & & & 3 & 88.73 & 7.55 & 0.20 & 3.52 & 17.60 \\
\hline 26 & $"$ & 6. & 8. & 8 & & & 3 & 86.98 & 6.14 & 1.42 & 5.46 & $3.8 \overline{0}$ \\
\hline 27 & $"$ & 6. & 8. & 8 & & & 20 & 83.21 & 7.64 & 0.88 & 8.27 & 9.40 \\
\hline 28 & $"$ (小洞) & 6. & 8. & 8 & & & & 0.73 & 0.00 & 20.00 & 70.27 & 3.964 \\
\hline 29 & $"$ (小洞) & 6. & 8. & 8 & & & & 0.80 & 0.46 & 19.16 & 79.58 & 4.15 \\
\hline 30 & 赤 霄 & 6. & 8. & 8 & & & & 79.46 & 1.04 & 1.28 & 18.22 & 14.23 \\
\hline
\end{tabular}

2. 定量試驗 以上の結果にて捕集瓦斯成分に變化を生する事索く分析するには現地に於て瓦斯䑾 集後成る可く迅速に分析せねばならぬ事を知つたので昭和 7 年度昭和 S . 作度に於ては次の如方法 にて現地分析を行つた。

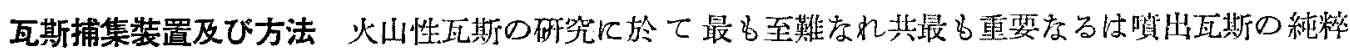
成分を瓦斯相互間に變化する事をく且つ他成分の混入する事なく捕集する事でする．加かる山瓦

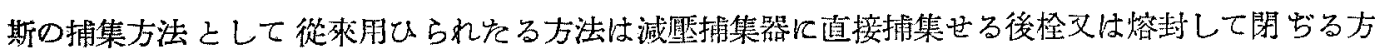

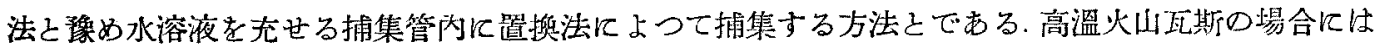
前者の方法が主に用ひられてをるがその純粹成分の捕集は甚だ至難こするところである，滥黑地帶 几於ては漂泉成因との關係上主として㴗泉之其江賃出する瓦斯を捕集したので後者の水溶液置换法

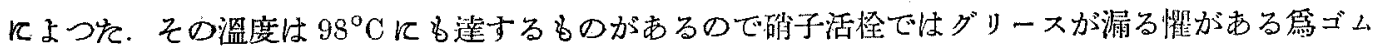

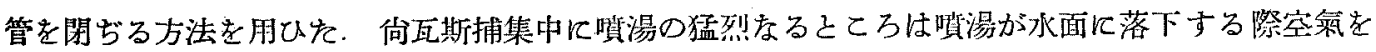

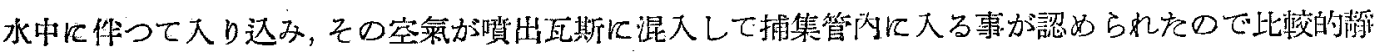

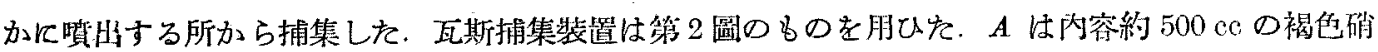
子製瓦斯捕集管で, $B$ は褐色硝子漏斗管, $C$ は鐵棒で $D$ なる金具により支へられ, $F$ 及び $G$ クランプ を支へる. $E$ は鐵管で長さ $5 \mathrm{~m}$ 迄接續し得るるので, 此の內部に $H$ なる硝子管を通し $J$ に連絡せし

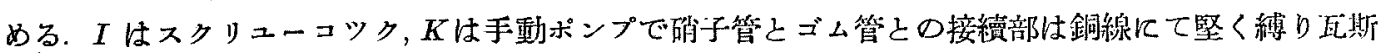
の渑らない樣にした。捕集方法は湧泉と共に貲出する瓦斯を捕集する時には $B$ なる漏斗管を約 $10 \mathrm{~cm}$ 


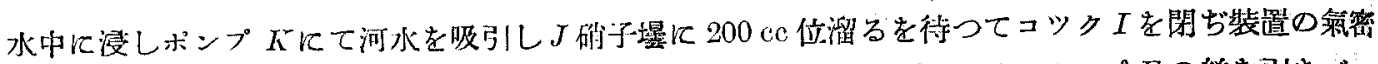

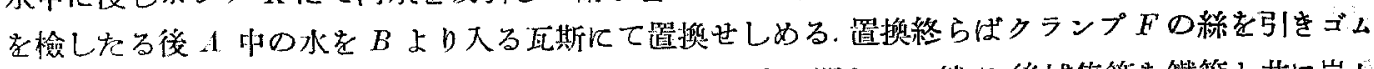

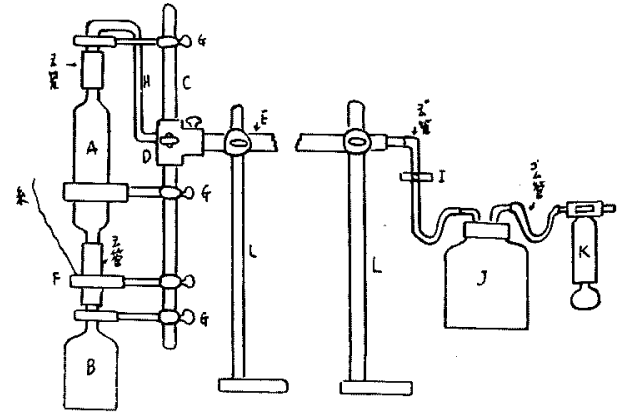

第 2 雨

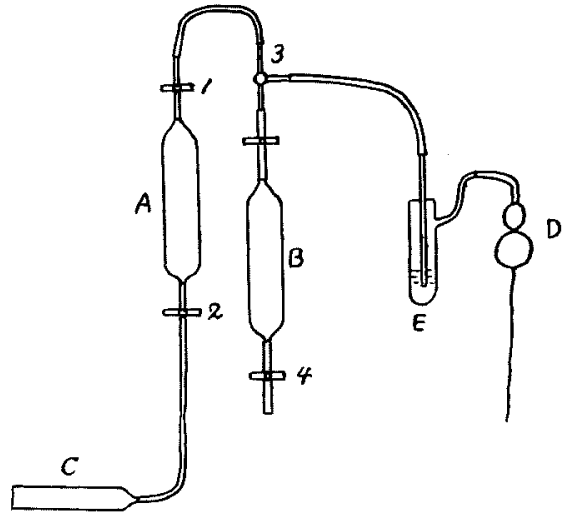

第 3 㜀 管を氣密に閉占る，然る後捕集管を鐵管と共に岸上 に引き揚げ $A$ 管兩端のゴム管をスクリユーコックに て氣密に閉ぢ直ちに現地分析場几て分析した，河岸 上の小洞より噴出する瓦斯の捕集には第3圖の如を裝

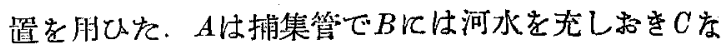
る細辰を漏斗管を小洞內約 $35 \mathrm{~cm}$ の哚さ迄差し込み たる後 $D$ なる吸引スプレーにて 1 秒間約 1 氣泡の速 さにて約30分間瓦斯を吸引し $A$ 內の空氣を小洞內瓦 斯にて置撸せしめ然る後 $B$ 內の水をスクリエーコッ ク4を州減して 1 游づつ滴下せしめ滴下終る前にA管 网端のスクリニーコツク 1,2 を閉ぢ直ちに分析した。

瓦斯分析法 現地分析を行ふには捕集瓦斯を乾燥 し水銀をビニレツト液をする事は不可能な事なので 捕集瓦斯を吸收する事度をビユレツト液を撰擇せね ばならない，その第に水溶液中から揊擇する事とし

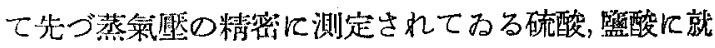
き $\mathrm{H}_{2} \mathrm{~S}, \mathrm{CO}_{2}$ 空氣等者朋U 60 回以上に亘り吸收試驗 を行つを絬果 $\mathrm{N}-\mathrm{H}_{2} \mathrm{SO}_{4}$ に一度混合瓦斯学吸收せし めたものは殆んど吸收力を有せずビユレツトにて試 驗せる結果は上䛌瓦斯にて吸收量を認められなかつ たのでこれをビニレツト液として用ひを，分析裝置 は第 4 圖の如きものでゴム管接續部以外は硝子接續 で定量用瓦斯の通路には毛細管を用ひた。 三方活柽

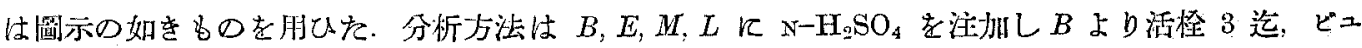

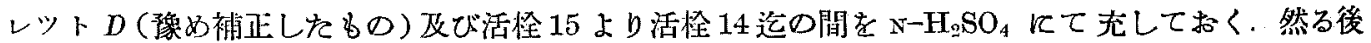
$A$ 試料管を圖示の如く空氣を少しる入れ樣にして接續する。㳄に $A$ 內の瓦斯をビュレツトD队

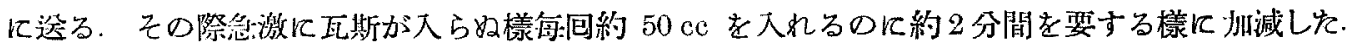

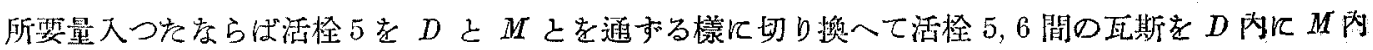

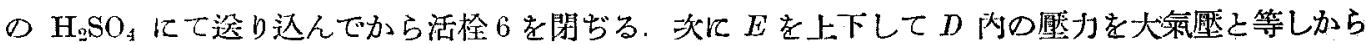

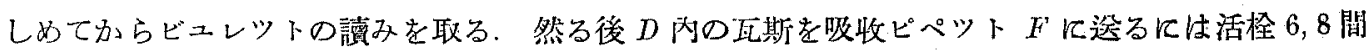

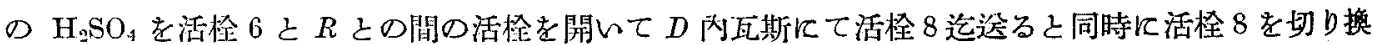

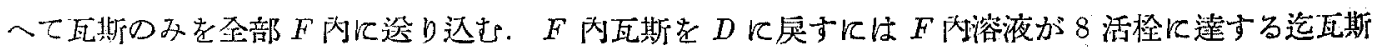

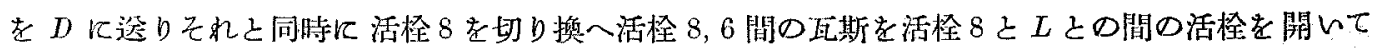

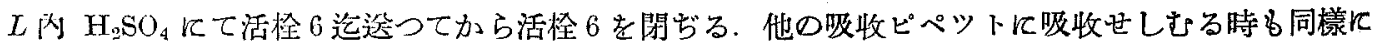
して外氣を少しる混入せしむる事なく操作する， $\mathrm{H}_{2} \mathrm{~S}$ の定量には $D$ にて一定量を取つをるのをQ内

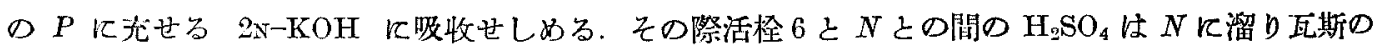

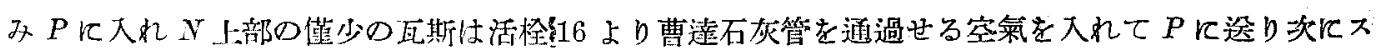




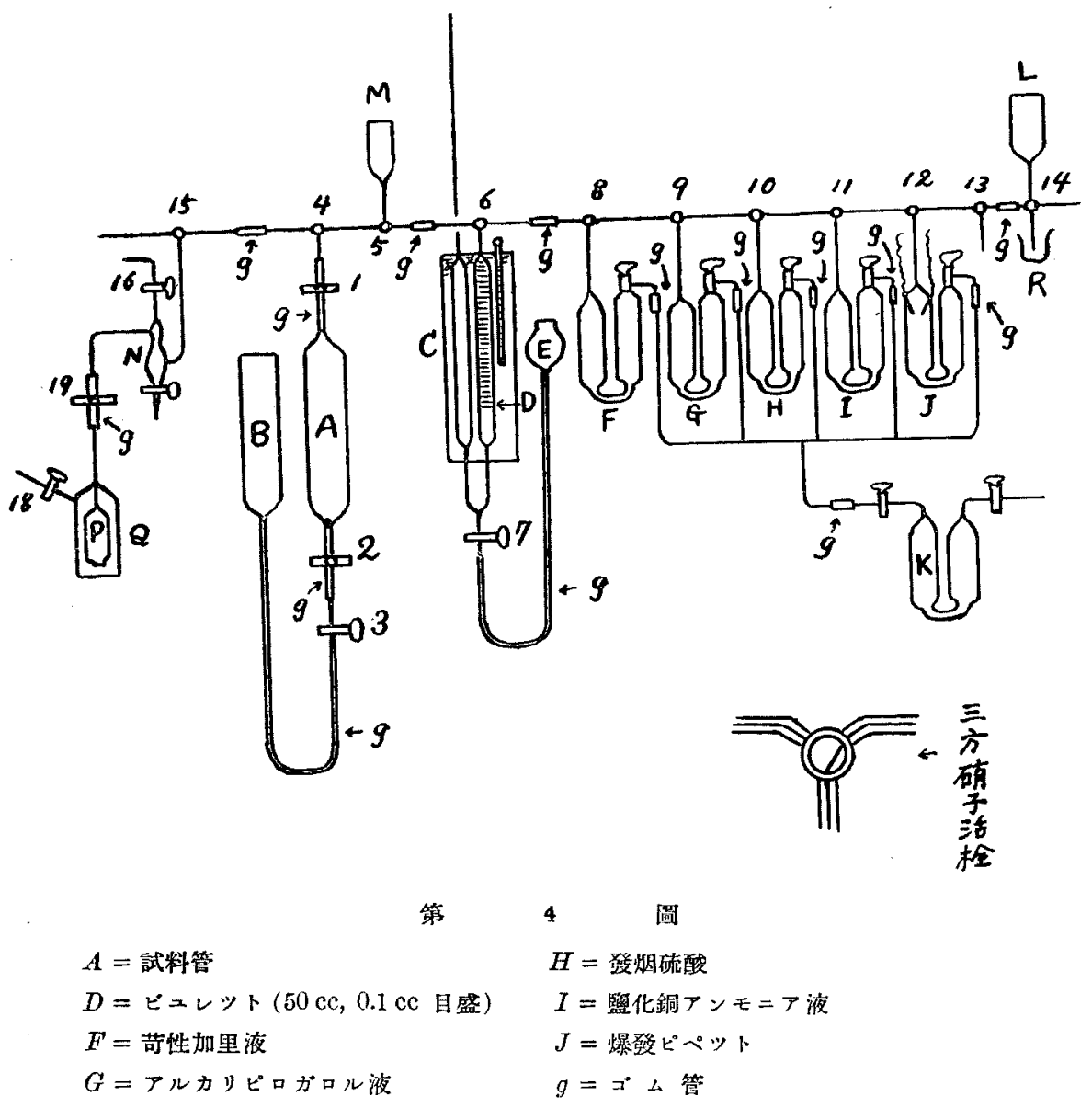

クリニーコツク 19 と活栓 18 とを閉ぢ充分吸收せしめてる後 $Q$ 内溶液を計量フラスコに移し簧校後 臭素にて酸化して $\mathrm{BaSO}_{4}$ として定量した. $\mathrm{CO}_{2}$ はピペツト $F$ にて吸收せるものから $\mathrm{H}_{2} \mathrm{~S}$ 容皘を差

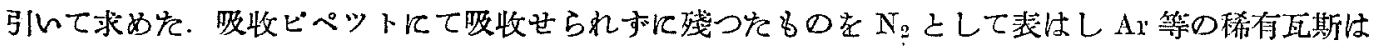

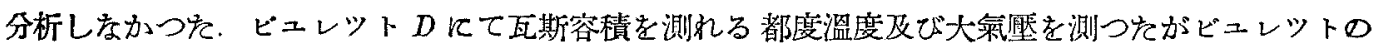

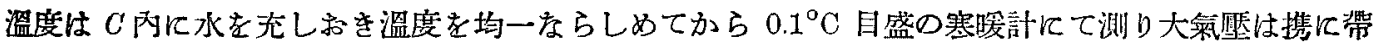

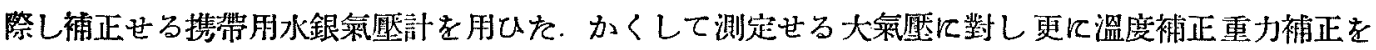

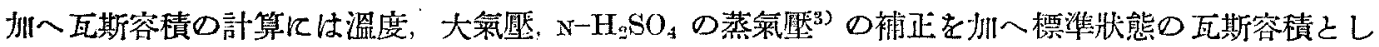
て計算した，上記の方法にて同一試料に就き試料の多いるのは4回行つて平均を取つたが試料の少

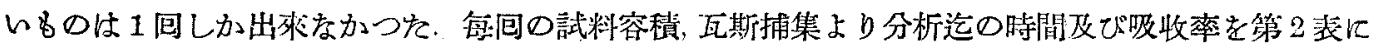
舉け゚る. 吸收ピペツト $F$ 及 $G$ 以外の吸收ピペットルよる吸收率は $0.02 \%$ 以下であつをので測定謨 差以內のるのとして計算しなかつを，上記の結果から計算した瓦斯成分を第 3 裴几舉げる（捕集場 所は第一報*第 1 圖, 第 3 圖, 第 4 圖, 第 5 圖参照)

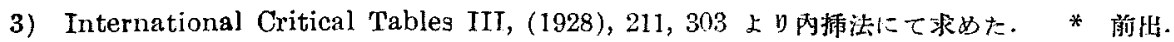


第 $\quad 2^{\circ}$ 表

\begin{tabular}{|c|c|c|c|c|c|c|c|c|c|c|c|c|c|c|c|}
\hline \multirow{2}{*}{ 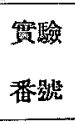 } & \multirow{2}{*}{ 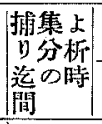 } & \multicolumn{4}{|c|}{ 取かる試料 (cc) } & \multicolumn{5}{|c|}{ 苛性加里液の吸收 (\%) } & \multicolumn{5}{|c|}{ アルカリピロガロール液の㽖收(\%) } \\
\hline & & 1 & 2 & 3 & 4 & 1 & 2 & 3 & 4 & 平均 & 1 & 2 & 3 & 4 & 平均 \\
\hline 31 & 120分 & 40.79 & & & & 93.33 & & & & & 1.08 & & & & \\
\hline 32 & 39分 & 40.93 & 41.02 & & & 96.21 & 96.20 & & & 96.21 & 0.10 & 0.10 & & & 0.10 \\
\hline 33 & 65分 & 40.36 & 39.85 & & & 84.56 & 84.57 & & & 84.57 & 1.78 & 1.73 & & & 1.76 \\
\hline 34 & 55分 & 40.24 & 40.28 & & & 91.63 & 91.68 & & & 91.66 & 1.27 & 1.26 & & & 1.27 \\
\hline 35 & 25 分 & 40.57 & & & & 86.25 & & & & & 1.53 & & & & \\
\hline 36 & 47分 & 39.52 & 39.60 & 39.86 & & 95.17 & 95.18 & 95.16 & & 95.17 & 0.53 & 0.53 & 0.55 & & 0.54 \\
\hline 37 & 50分 & 40.08 & 39.95 & & & 92.54 & 92.52 & & & 92.53 & 1.10 & 1.10 & & & 1.10 \\
\hline 38 & 50分 & 39.93 & 39.85 & & & 96.39 & 96.39 & & & 96.39 & 0.28 & 0.23 & & & 0.26 \\
\hline 39 & 35分 & 40.46 & 40.45 & 40.26 & & 97.80 & 97.78 & 97.79 & & 97.79 & 0.22 & 0.22 & 0.20 & & 0.21 \\
\hline 40 & 24分 & 40.16 & 39.85 & 40.08 & & \begin{tabular}{|l|}
95.99 \\
\end{tabular} & $\begin{array}{l}95.96 \\
\end{array}$ & 96.01 & & 95.99 & 0.57 & 0.58 & 0.52 & & 0.56 \\
\hline 41 & 55分 & 39.70 & 39.88 & & & 95.19 & 95.19 & & & 95.19 & 0.50 & 0.48 & & & 0.49 \\
\hline 42 & 55分 & 39.72 & 39.89 & & & 98.04 & 98.04 & & & 98.04 & 0.28 & 0.28 & & & 0.28 \\
\hline 43 & 114日 & 47.25 & 47.52 & 47.61 & 47.59 & 91.72 & 91.77 & 91.70 & 91.76 & 91.74 & 0.42 & 0.42 & 0.46 & 0.40 & 0.43 \\
\hline 44 & 112日 & 46.47 & 47.60 & & & 97.40 & 97.42 & & & 97.41 & 0.09 & 0.08 & & & 0.09 \\
\hline 45 & 170 分 & 40.21 & 40.48 & 40.80 & & 98.21 & 98.20 & 98.16 & & 98.19 & 0.17 & 0.20 & 0.22 & & 0.20 \\
\hline 46 & 42 分 & 41.56 & 41.39 & 41.24 & & 97.81 & 97.80 & 97.79 & & 97.80 & 0.22 & 0.22 & 0.22 & & 0.22 \\
\hline 47 & 30 分 & 41.51 & 41.44 & 41.81 & & 96.48 & 96.53 & 96.51 & & 96.51 & 0.34 & 0.36 & 0.33 & & 0.34 \\
\hline 48 & 28 分 & 41.50 & 41.30 & 41.33 & & 92.43 & 92.40 & 92.40 & & 92.41 & 1.01 & 0.97 & 0.97 & & 0.99 \\
\hline 49 & 30分 & 41.46 & 41.59 & & & \begin{tabular}{|l|}
77.64 \\
\end{tabular} & 77.59 & & & 77.62 & 2.29 & 2.36 & & & 2.33 \\
\hline 50 & 29分 & 42.64 & 42.09 & 42.71 & & \begin{tabular}{|l}
95.85 \\
\end{tabular} & 95.87 & 95.83 & & 95.85 & 0.16 & 0.14 & 0.16 & & 0.15 \\
\hline 51 & 30分 & 42.12 & 42.14 & 41.81 & & 97.82 & 97.82 & 97.80 & & 97.81 & 0.19 & 0.19 & 0.19 & & 0.19 \\
\hline 52 & 30 分 & 41.56 & 39.94 & 41.45 & & 96.61 & 96.59 & 96.60 & & 96.60 & 0.36 & 0.36 & 0.34 & & 0.35 \\
\hline 53 & 65 分 & 41.06 & 41.43 & 41.24 & & 94.37 & 94.42 & 94.40 & & 94.40 & 0.10 & 0.10 & 0.10 & & 0.10 \\
\hline 54 & 20 分 & 40.95 & 40.32 & & & 98.22 & 98.22 & & & 98.22 & 0.27 & 0.27 & & & 0.27 \\
\hline 55 & 41分 & 40.33 & 40.41 & 40.17 & & 91.82 & 91.79 & 91.86 & & \begin{tabular}{|l|}
91.82 \\
\end{tabular} & 1.22 & 1.21 & 1.17 & & 1.20 \\
\hline 56 & 20分 & 40.47 & 40.67 & & & 98.05 & 98.11 & & & 98.08 & 0.12 & 0.07 & & & 0.10 \\
\hline 57 & 40 分 & 40.43 & 40.32 & 40.29 & & 74.89 & 74.88 & 74.91 & & 74.89 & 3.17 & 3.15 & 3.15 & & 3.16 \\
\hline 58 & 27 分 & 40.09 & 40.03 & 40.21 & & 98.15 & 98.20 & 98.16 & & 98.17 & 0.20 & 0.20 & 0.20 & & 0.20 \\
\hline 59 & 15 分 & 40.62 & 40.39 & 40.71 & & 96.23 & 96.29 & 96.29 & & 96.27 & 0.15 & 0.12 & 0.15 & & 0.14 \\
\hline 61 & 60 分 & 40.07 & 40.17 & 40.33 & & 94.56 & 94.55 & 94.55 & & 94.55 & 0.45 & 0.45 & 0.45 & & 0.45 \\
\hline 62 & 210 分 & 25.60 & & & & 0.74 & & & & & 20.82 & & & & \\
\hline 63 & 104日 & 44.64 & & & & 0.78 & & & & & 20.56 & & & & \\
\hline 64 & 100 分 & 39.58 & 39.64 & 39.42 & & 98.08 & 98.03 & 98.07 & & 98.06 & 0.10 & 0.13 & 0.10 & & 0.11 \\
\hline 65 & 20 分 & 39.78 & 39.71 & 36.69 & & 99.15 & 99.14 & 99.14 & & 99.14 & 0.20 & 0.20 & 0.20 & & 0.20 \\
\hline 66 & $101 日$ & 46.58 & & & & 93.75 & & & & & 1.65 & & & & \\
\hline
\end{tabular}

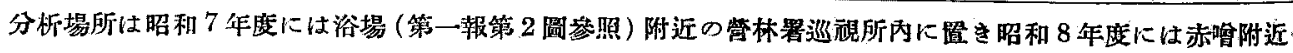
南岸上の小屋队に置いた。 
第 3 表 噴出正斯成分表（昭和 7 年，昭和 8 年)

\begin{tabular}{|c|c|c|c|c|c|c|c|c|c|c|}
\hline \multirow{2}{*}{$\begin{array}{l}\text { 頙 醶 } \\
\text { 番 號 } \\
\end{array}$} & 埸 & \multirow{2}{*}{ 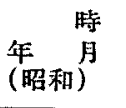 } & \multirow{2}{*}{$\begin{array}{c}\text { 溫 } \\
{ }^{\circ} \mathrm{C}\end{array}$} & \multirow{2}{*}{$\begin{array}{c}\text { 大氣压 } \\
\mathrm{mm}\end{array}$} & \multirow{2}{*}{$\begin{array}{c}\text { 深 さ } \\
\mathrm{cm}\end{array}$} & \multicolumn{4}{|c|}{ 瓦 斯 成 分 (\%) } & \multirow{2}{*}{$\begin{array}{l}\mathrm{N}_{2} \\
\mathrm{O}_{2}\end{array}$} \\
\hline & 20 & & & & & $\mathrm{CO}_{2}$ & $\mathrm{H}_{2} \mathrm{~S}$ & $\mathrm{O}_{2}$ & $\mathrm{~N}_{2}$ & \\
\hline 32 & 大津北岸 & $\begin{array}{lll}\text { 7. } & 8 . & 7\end{array}$ & 95.8 & & & 75.45 & 20.76 & 0.10 & 3.69 & 36.90 \\
\hline 38 & $\prime \prime$ & 7. 8.10 & & & & 72.61 & 23.78 & 0.26 & 3.35 & 12.88 \\
\hline 50 & $"$ & 7. $9 . \quad 8$ & 97.0 & & 17 & 79.29 & 16.56 & $0.1 \tilde{5}$ & 4.00 & 26.67 \\
\hline 59 & $"$ & 8. 8. 11 & 96.6 & 696 & 16 & 77.34 & 18.93 & 0.14 & 3.59 & 25.64 \\
\hline 34 & 大沸北崖喷泉 & $\begin{array}{lll}7 . & 8 . & 8\end{array}$ & 94.3 & 707 & & 76.89 & 14.77 & 1.27 & 7.07 & 5.57 \\
\hline 37 & $"$ & $\begin{array}{lll}7 . & 8 . & 10\end{array}$ & & & & 76.06 & 16.47 & 1.10 & 6.37 & 5.79 \\
\hline 48 & $"$ & $\begin{array}{lll}7 . & 9 . & 7\end{array}$ & 93.0 & & 6 & 75.43 & 16.98 & 0.99 & 6.60 & 6.67 \\
\hline 55 & $"$ & 8. 8.7 & 95.5 & 697 & 5 & 77.72 & 14.10 & 1.20 & 6.98 & 5.82 \\
\hline 33 & 大沸南岸噴泉 & $\begin{array}{lll}7 . & 8 . & 8\end{array}$ & 98.1 & 707 & & 66.62 & 17.95 & 1.76 & 13.67 & 7.77 \\
\hline 35 & $"$ & 7. 8.9 & & & & 68.77 & 17.48 & 1.53 & 12.22 & 7.99 \\
\hline 49 & $"$ & 7. 9.7 & 97.3 & & 30 & 69.48 & 8.14 & 2.33 & 20.05 & 8.61 \\
\hline 57 & $"$ & 8. 8. 10 & 97.2 & 697 & 17 & 63.03 & 11.86 & 3.16 & 21.95 & 6.95 \\
\hline 31 & 大 沸 & 7. 8.6 & 96.9 & 706 & & 75.21 & 18.12 & 1.08 & 5.59 & 5.18 \\
\hline 36 & 大昲 & $\begin{array}{lll}7 . & 8 . & 9 \\
\end{array}$ & 91.0 & & 6 & 74.07 & 21.10 & 0.54 & 4.29 & 7.94 \\
\hline 39 & 棚西噴泉 & 7. 8.11 & 95.5 & 706 & & 83.18 & 14.61 & 0.21 & 2.00 & 9.52 \\
\hline $44^{x}$ & $"$ & 7. 8. 14 & & & & 86.33 & 11.08 & 0.09 & 2.50 & 27.78 \\
\hline 46 & $"$ & $\begin{array}{lll}\text { 7. } & 9 . & 6\end{array}$ & 95.6 & & 20 & 84.61 & 13.19 & 0.22 & 1.98 & 9.00 \\
\hline 51 & $"$ & $\begin{array}{lll}\text { 7. } & 9 . & 8\end{array}$ & 95.6 & & 20 & 84.20 & 13.61 & 0.19 & 2.00 & 10.53 \\
\hline 58 & $"$ & 8. 8. 10 & 89.4 & 697 & 24 & 85.90 & 12.27 & 0.20 & 1.63 & 8.15 \\
\hline 40 & 湯花用水門 & 7. 8.11 & 56.7 & 706 & & 81.28 & 14.71 & $0 . \tilde{6}$ & 3.45 & 6.16 \\
\hline 47 & $"$ & 7. 9.7 & & & & 79.97 & 16.54 & 0.34 & 3.15 & 9.26 \\
\hline 52 & $"$ & 7. 9. & & & & 81.47 & 15.13 & 0.35 & $3.05^{\circ}$ & 8.71 \\
\hline 46 & $"$ & 8. 8. 10 & 63.1 & 685 & 5 & 79.36 & 18.72 & 0.10 & 1.82 & 18.20 \\
\hline 42 & 小 洞 & 7. 8. 13 & 51.6 & & & 72.65 & 25.39 & 0.28 & 1.68 & 6.00 \\
\hline 54 & $"$ & $\begin{array}{lll}\text { 7. } & 9 . & 9\end{array}$ & & & & 73.77 & 24.45 & 0.27 & 1.51 & 5.59 \\
\hline 65 & $"$ & 8. $\quad 8.12$ & & & 45 & 71.13 & 28.01 & 0.20 & 0.66 & 3.30 \\
\hline $66^{x}$ & $"$ & 8. $\quad 8 . \quad 12$ & & & & 80.95 & 12.80 & 1.65 & 4.60 & 2.79 \\
\hline 41 & 赤 & 7. 8.13 & & & 65 & 89.75 & 5.44 & 0.49 & 4.32 & 8.82 \\
\hline $43^{x}$ & $"$ & $\begin{array}{lll}7 . & 8 . & 14\end{array}$ & 70.6 & & & 77.65 & 14.09 & 0.43 & 7.83 & 18.21 \\
\hline 53 & $"$ & $\begin{array}{lll}\text { 7. } & 9 . & 8\end{array}$ & 46.5 & & & 78.68 & 15.72 & 0.10 & 5.50 & 55.00 \\
\hline 61 & $"$ & 8. - 8. 11 & 68.2 & 698 & 35 & 83.36 & 11.19 & 0.45 & 5.00 & 11.11 \\
\hline 62 & 殺 生 澤 & 8. 8.12 & 43 & & & 0.74 & tr. & 20.82 & 78.44 & 3.768 \\
\hline $63^{x}$ & $"$ & $\begin{array}{lll}\text { 8. } & \text { 8. } & 12 \\
\end{array}$ & & & & 0.78 & tr. & 20.56 & 78.66 & 3.826 \\
\hline 45 & 山 & 7. 8.15 & 89.6 & 655 & & 79.21 & 18.98 & 0.20 & 1.61 & 8.05 \\
\hline 64 & 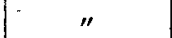 & 8. $\quad$ 8. 12 & 91.2 & 656 & & 81.24 & 16.82 & 0.11 & 1.83 & 16.64 \\
\hline
\end{tabular}

說明 (1) 小洞及び殺生裂以外のるのは總て水中より出る瓦斯を捕集したるので深さは水中にて测り得られた丈

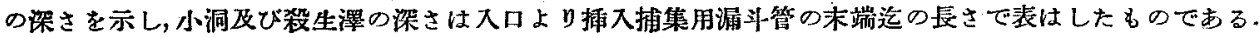

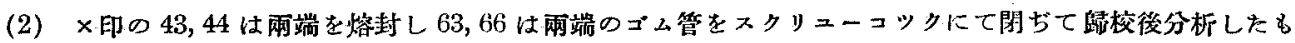
のである。

(3) 溫度は $0.1^{\circ} \mathrm{C}$ 目盛最高寒暖計にて測り.大氮厴はアネロイド型氣医計にて現埸にて測つたものであ る.（网者共㐨め䋠正したるのを用ひた）

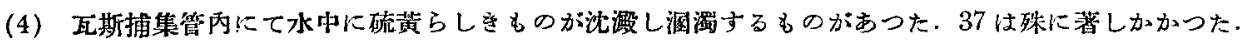




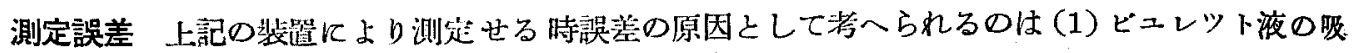
收に因るるの，(2) ビュレツトの讀み取りより來るもの，(3) 溫度變化に因るるの，(4)大氣壓變化に

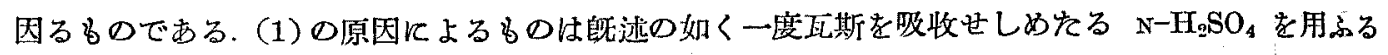
時は誤差なをるのと看做される（2）の原因によるるのは $0.1 \mathrm{cc}$ 目盛のビニレツトを朋ひたから 0.01 cc の誤差は免かれないるのをると $50 \mathrm{cc}$ に對し $0.02 \%$ の誤差が入る.（3）の原因によるるのは溫度

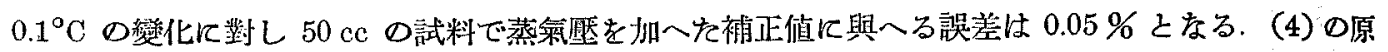
因によるるのは大氣厴 $0.1 \mathrm{~mm}$ の美で補正值に與へる誤茎は $0.01 \%$ 以で無視し得るるのである から以上 4 つの原因より來る誤差は $0.07 \%$ 以內である. 從つて上記の裝置にて $0.07 \%$ 以內の精密 度にて测定される，测定の結果も第2表に示せる如く可なり良を一致を示してをる。

\section{II. 瓦斯定量結果の比較考案}

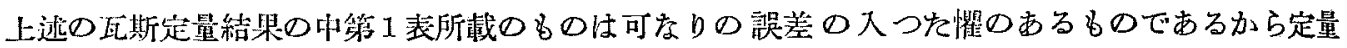
試驗結果として此れに言及する事を止め第 3 表の絬果に就を時閏的變化その他に就を洘察してみる.

1. 時間的變化 同一場所より貸出する瓦斯成分は時閒的に變化するか或は常に同一成分を櫴出す るかを比較する。.

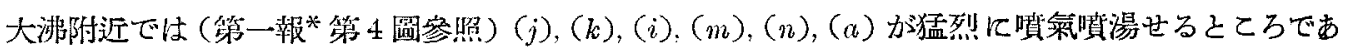

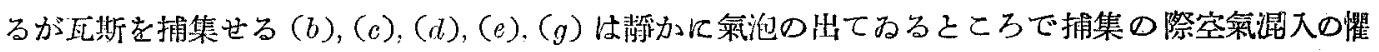
はなかつた。第3表にて大沸北岸のものは $\mathrm{O}_{2}, \mathrm{~N}_{2}$ は變化が少いが $\mathrm{CO}_{2}$ と $\mathrm{H}_{2} \mathrm{~S}$ とは 3 日後のものでも

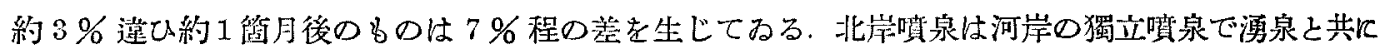

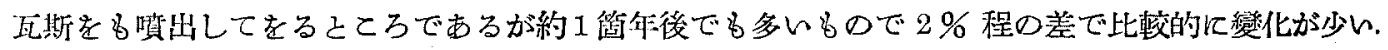
南岸貲泉は獨立貲泉で湧泉と共に瓦斯を猉出してなる所であるが $\mathrm{CO}_{2}, \mathrm{H}_{2} \mathrm{~S}, \mathrm{~N}_{2}$ の變化甚だしく，多

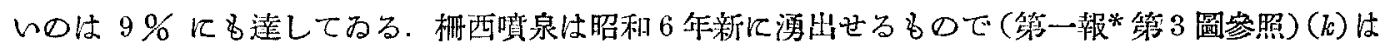

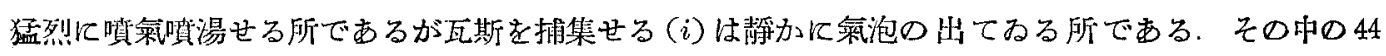
は歸校後分析せるもので捕集より分析迄第 2 表所械如の長時間を要してみるので他の同樣るる 43 , 63,66 之共に継めて後に述べる事として他の $39,46,51,58$ を比較する之變化が少い．湯花用水門の

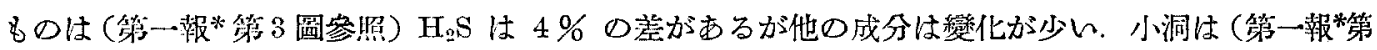

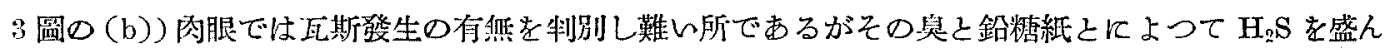
に嘪出してるる事が知られる，河岸上の口徑 $5 \mathrm{~cm}$ 程の空洞ををせる小洞で 66 以外のものは $\mathrm{H}_{\mathrm{g}} \mathrm{S} て ゙$ $4 \%$ 程の差のものがあるが變化は少い方でする. 赤噲は湧泉之共に瓦斯を貲出してるる所で湯花を探 集する時は此處に上流よりの河水が林通により流入せられてみるのであるが(第一報*第 5 圖參照， $41,43,61$ はかかる河水の流入せる狀態にて瓦斯を捕集せるるので53のみは流大河水を止め赫のる の溥泉とせる時唄出瓦斯を捕集せるものでする。而も捕集場所は嚴密几同一場所から捕集する事は 不可能であつたので凡そ一平方米以內の地域から唭出せるるのを捕集した，その中 43 を除外しても $\mathrm{CO}_{2}, \mathrm{H}_{2} \mathrm{~S}$ は藷しく變化し $12 \%$ る蓬してみる. 此れは上述の如く 53 之他のるのとは捕集時の條件

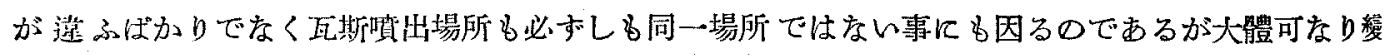

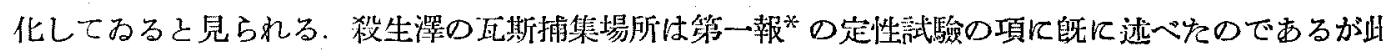
の资量結果から考へると瓦斯貲出の少なかつた場所から捕集したものと思はれる，燒山のるのは(第

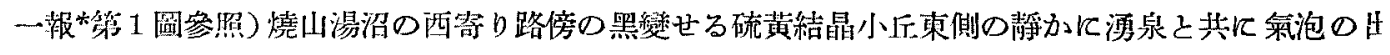

* 前织. 
てるる所から捕集したもので $\mathrm{CO}_{2}, \mathrm{H}_{2} \mathrm{~S}$ 兩者共 $2 \%$ の烍で比校的に變化が少い. 以上の絬果昭和 7

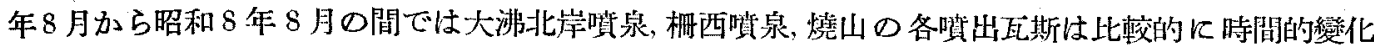
が少く，大沸北岸，大沸南岸資泉，赤噲の各貲出瓦斯は可なり時間的變化が多い事を示してるる. 次に

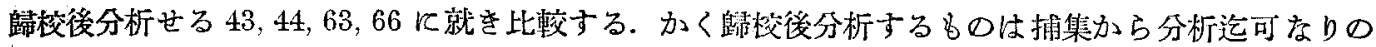
時間を要するのでその間に瓦斯成分が變化するかどらかを試驗する䉆行つたるのであるが時閒的變 化が多い場所で怊え絕成分が變化してなると考へられるので全く同特㭪集したものでなければ 比較試驗にはならないのでする，かかる條件に適合するbのは 66 と 65 とであるが $\mathrm{H}_{2} \mathrm{~S} か ゙ 15 \%$ る 減少してるる. 此れは如何なる原因によるか明らかでないが保存中に變化せるものと若へられるので

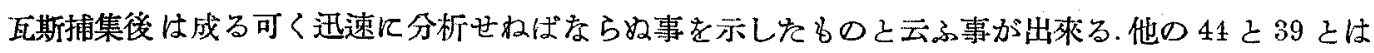

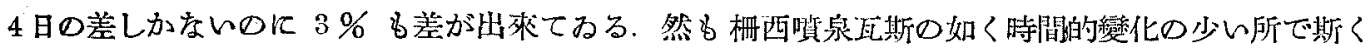

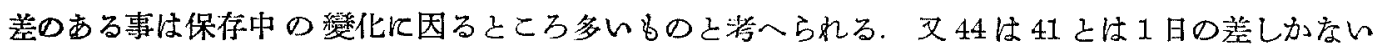
が $\mathrm{CO}_{2}, \mathrm{H}_{2} \mathrm{~S}$ は $10 \%$ 以上も違つてねる. これを捕集せる赤噲注時閒的變化の多いこてろであるが，

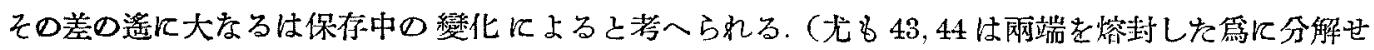

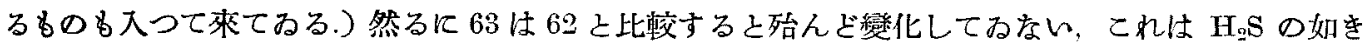

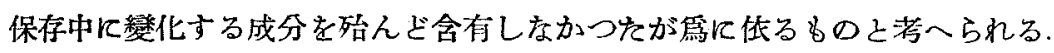

2. 噴出場所による變化 噴出場所の遠ふ事により如何に瓦斯成分に變化があるかを比較する.大 沸附近几於て (第一報*第 4 圖參照) 瓦斯を捕集せる所は河中の北岸 $(c)$ そ乙の附近の $(b)$ 及び (d)

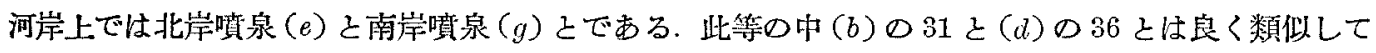

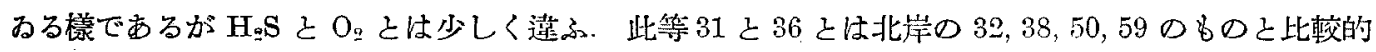
に類似してるる樣に見えるが北岸のるのは $O_{2}$ の少い點で明らかに區別される，31は叉北岸噴泉の $34,37,48,550$ もとも類似してをる漛に見えるが 31 は $\mathrm{H}_{2} \mathrm{~S}$ が多く $\mathrm{N}_{2}$ が少い，此等 $(e),(d),(e)$

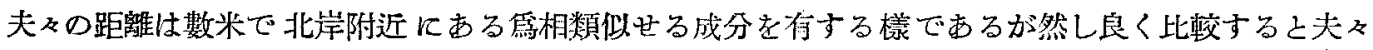
特異の成分割合存する事が看取される. かく夫及特異の成分割合を倠与る事は夫及獨立の經路を

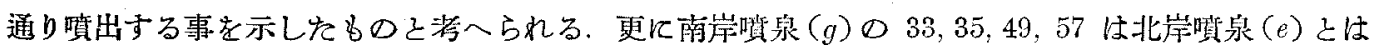
數米しか離れてるないにも拘らす北岸噴泉のものとは全く異なる成分割合をなしてをる事は夫及獨

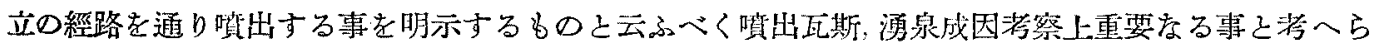
れるのである．大沸下流方面の柵西璂泉, 湯花用水門, 小洞, 赤哈のものを比較するに(第一報第3

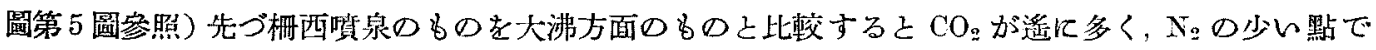
特異の成分割合をなしてみる事が知られる，更に湯花用水門のるのをてれる比較する之類似してる

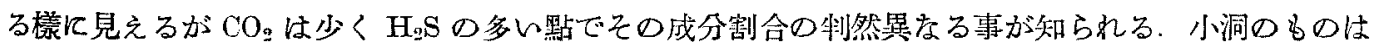

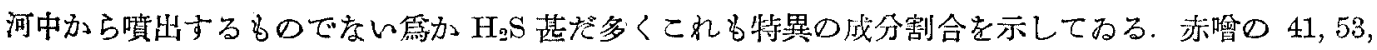

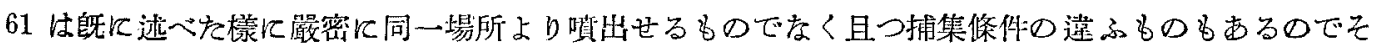

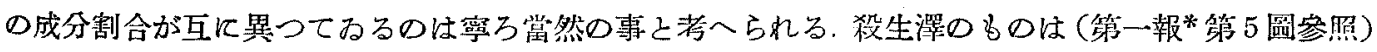

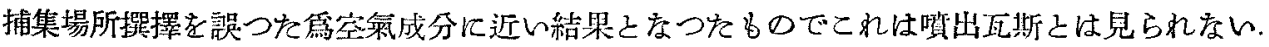

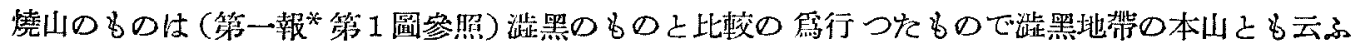

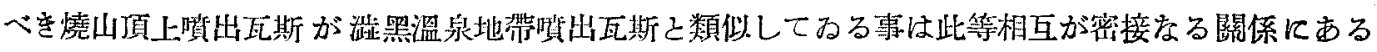
事を示すものと㗳へられる. 然し良く比较すると焼山のるのは $\mathrm{N}_{2}, \mathrm{O}_{2}$ の少い點で恃柵西噴泉及び小洞 のものに類似してみるが $\mathrm{H}_{2} \mathrm{~S}, \mathrm{CO}_{2}$ は此等网者の中間になつてみて燒山のものとしての特異の成分割

* 前出. 
合を持つてるる. 以上の結果加ら瓦斯㩫出場所の異なるに從ひ貲出瓦斯ても夫る特異の成分割合を有

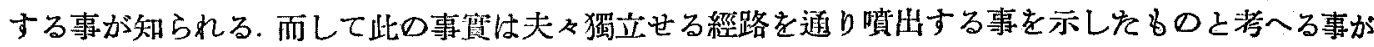
出來る．然し此等獨立經路之踓名近接のbのは互に地下に於て連絡のある可事は考へられる事で

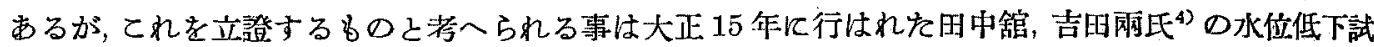

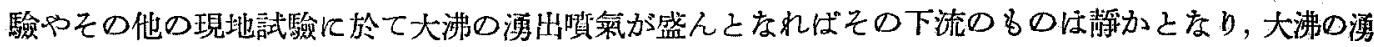

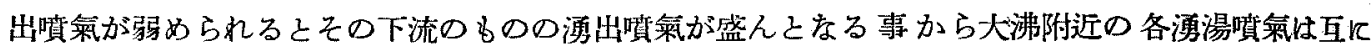

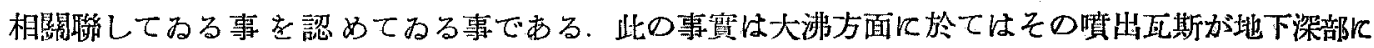
於ては互に連絡する事を證するるのと考へられる，以上の獨立經路索通るといふ事と近接のものは

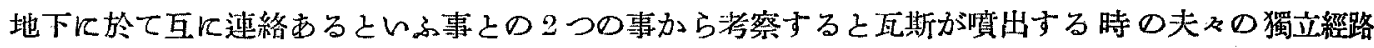
にはその深度に限度があつて,その深度以下に於ては同一源をなしてわるがそれより分歧して夫ょの 獨立の經路を通り貲出するに至るるのと考へられる. 而して各ねが特異の成分割合を有するのは夫 夫の獨立經路を通る間に變化するに因るものと洘へられる。

份櫴出瓦斯成分の成因に就宊ては後報に於て逝べる.

\section{III. 總括}

（1）昭和 5 年及び昭和 6 年に現地にて捕集せる瓦斯を踏校後定量分析して捕集瓦斯成分を變化す る事なく分析し得るかを試驗した結果滿足なる結果を得られなかつたので捕集後成る可く迅速に分 析にかける樣現地分析を行ふ事とした.

（2）昭和 7 年及び昭和 8 年には現地定量分析を行ひ，その得をる結果に就を筫出瓦斯の時間的變 化及び噴出場所による變化に就を比較した結果, 同一場所の時間的變化に就きては場所によつて多い 所と少い所とがあり少いるのは $2 \%$ 位であるが多いるのは $9 \%$ にる達し1日後のるのでる2\%の 差老生ずるるのるすつて大體に於て同一場所上り噴出する瓦斯成分は多少共絕え示變化しつつある 事が認められた，噴出場所による變化に就をては比較的近距離のるのと踓も場所の異なるに從ひ夫 夫特異の成分割合を有する事が認められた．以上の事から地下深部に於ては同一源の瓦斯でもそれよ り分忮して夫及獨立經路を通り噴出し異なれる成分割合として發生するに至るべき事を若察した。

本研究に對し研究費を補助せられたる齋藤報恩會に對し感謝の意を表する．向瓦斯の捕集に助力 せる今野善市君に謝意を表する。

（秋田鐿山曹門學校）

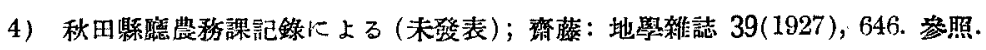

